\title{
Kajian Hidrolika Aliran Bangunan Pelimpah Samping (Side Channel Spillway) Bendungan Beringin Sila Kabupaten Sumbawa
}

\author{
Nanda Aulia ${ }^{1}$, Very Dermawan ${ }^{1}$, Evi Nur Cahya ${ }^{1}$ \\ ${ }^{1}$ Jurusan Teknik Pengairan, Fakultas Teknik, Universitas Brawijaya, \\ Jalan Mayjen Haryono No.167, Malang, 65145, Indonesia \\ *Korespondensi Email: ailuana19@gmail.com
}

\begin{abstract}
The construction of the Beringin Sila dam is a priority to provide irrigation water and meet raw water requirements in the Utan and Buer districts. To address this issue, the Beringin Sila Dam is one of the government's efforts to build equitable infrastructure to support national water and food safety. The hydraulic analysis of the physical design of the Beringin Sila dam is one of the planning rules for the dam. The goal of the analysis of the physical model of the Beringin Sila dam is to evaluate and propose the best alternative to improve the overall hydraulic performance based on initial planning. The hydraulic analysis of the physical model of the Beringin Sila dam was carried out with the initial planning of the series 0 using the standard stage method on the transition channel and the chute way. The physical model test results show that the design of the dam is safe to flow the Q100th and Q1000th discharge because the conditions of the transition channel are not crossflow, the chute way channel is supercritical and there is no capitation and vibration flow.
\end{abstract}

Keywords: Dams, Hydraulic, Models test, Spillway.

Abstrak: Kontruksi Bendungan Beringin Sila diprioritaskan untuk suplai air irigasi dan memenuhi kebutuhan air baku di kecamatan Utan dan kecamatan Buer. Untuk mengatasi masalah ini, pembangunan Bendungan Beringin Sila adalah salah satu upaya pemerintah dalam mewujudkan pemerataan pembangunan infrastruktur untuk mendukung ketahanan air dan ketahanan pangan nasional. Analisis hidrolik model fisik Pelimpah Bendungan Beringin Sila merupakan salah satu prosedur untuk perencanaan bendungan. Tujuan dari analisis model fisik Bendungan Beringin Sila adalah meneliti dan memberikan alternatif terbaik bagi peningkatan kinerja hidrolik pelimpah keseluruhan berdasarkan perencanaan awal. Analisis hidrolik model fisik Bendungan Beringin Sila dilakukan berdasarkan perencanaan awal seri 0 dengan menggunakan metode tahapan standar pada saluran transisi dan peluncur. Hasil uji model fisik menunjukkan bahwa desain bendungan telah aman untuk mengalirkan debit $\mathrm{Q}_{100 \text { th }}$ dan $\mathrm{Q}_{1000 \text { th }}$ dikarenakan kondisi saluran transisi tidak terjadi aliran silang, pada saluran peluncur kondisi aliran yaitu superkritis dan tidak terdapat kavitasi dan aliran getar.

Kata Kunci: Bendungan, Hidrolika, Pelimpah, Uji model. 


\section{Pendahuluan}

Di tanah air ini, pembangunan bendungan merupakan salah satu upaya mewujudkan fungsi dan manfaat misalnya untuk irigasi, sehingga dapat mewujudkan tingkat ekonomi dan kesejahteraan masyarakat. Salah satu daerah yang perlu dan patut dikembangkan mengenai perihal tersebut adalah Desa Tengah Kecamatan Utan Kabupaten Sumbawa Provinsi Nusa Tenggara Barat. Lokasi rencana Bendungan Beringin Sila berada di Sungai Utan yang merupakan sungai utama, mengalir dari arah selatan menuju utara. Di sebelah hilir rencana bendungan Beringin Sila terdapat Bendungan Beringin Sila yang saat ini mengairi areal irigasi seluas \pm 2.400 hektar [1].

Sebagai bendungan yang memiliki fungsi utama untuk sumber irigasi, Bendungan Beringin Sila diharapkan dapat menjadi salah satu alternatif agar tetap tersedia kebutuhan air untuk wilayah pertanian, dengan inflow tahunan andalan $80 \%$ diperkirakan mencapai 82 juta $\mathrm{m}^{3}$. Dengan kapasitas sebesar itu, aliran air yang ditampung dan diatur mampu mengairi areal irigasi seluas 2.400 hektar dengan capaian rerata intensitas tanam $160 \%$ dalam setahun dan dapat mencukupi kebutuhan air baku masyarakat sekitar serta mendukung kinerja PLTMH dengan potensi 0,50 MW.

Kondisi aliran di pelimpah sulit didekati dengan perhitungan analitik oleh karena itu perlu dilakukan pemodelan untuk mengetahui kondisi aliran yang sebenarnya [2]. Dengan dilakukan uji model fisik tujuannya untuk memperoleh kesempurnaan desain dan dapat mengetahui kondisi aliran pada sistem bangunan pelimpah [3]. Uji model fisik ini meliputi saluran samping, saluran transisi, saluran peluncur, peredam energi dan tail water level Bendungan Beringin Sila.

Setelah mengetahui kondisi pengukuran desain original pada pelimpah Bendungan Beringin Sila kemudian dilanjutkan membandingan hasil uji model fisik hidrolik dengan analisa hidrolika secara teoritis.. Diharapkan penelitian ini bisa menjadi sarana informasi yang akurat guna menetapkan upaya-upaya perbaikan hidrolika apabila suatu saat terdapat perencanaan bendungan lain dengan kondisi bangunan pelimpah dan bangunan pelengkap yang hampir sama.

\section{Bahan dan Metode}

\subsection{Bahan}

Lokasi studi Bendungan Beringin Sila berada di Sungai Utan Desa Tengah Kecamatan Utan Kabupaten Sumbawa Provinsi Nusa Tenggara Barat [1]. Secara geografis Bendungan Beringin Sila terletak sekitar $8^{\circ} 27^{\prime} 43.77^{\prime \prime}$ LS dan $117^{\circ} 7^{\prime} 21.17^{\prime \prime}$ BT atau pada koordinat $\mathrm{X}=513.489,62$ dan $\mathrm{Y}=9.064 .607,83$ berjarak 600 meter di atas Bendung Beringin Sila.

Data-data yang diperlukan untuk analisis dalam studi ini antara lain:

- Data Teknis Bendungan

- Data Teknis Model Test

- Data hasil pengukuran tinggi muka air pada model fisik

- Data hasil pengukuran kecepatan aliran pada model fisik

- Data hasil Evaluasi Kavitasi Berdasarkan Hasil Pengujian 


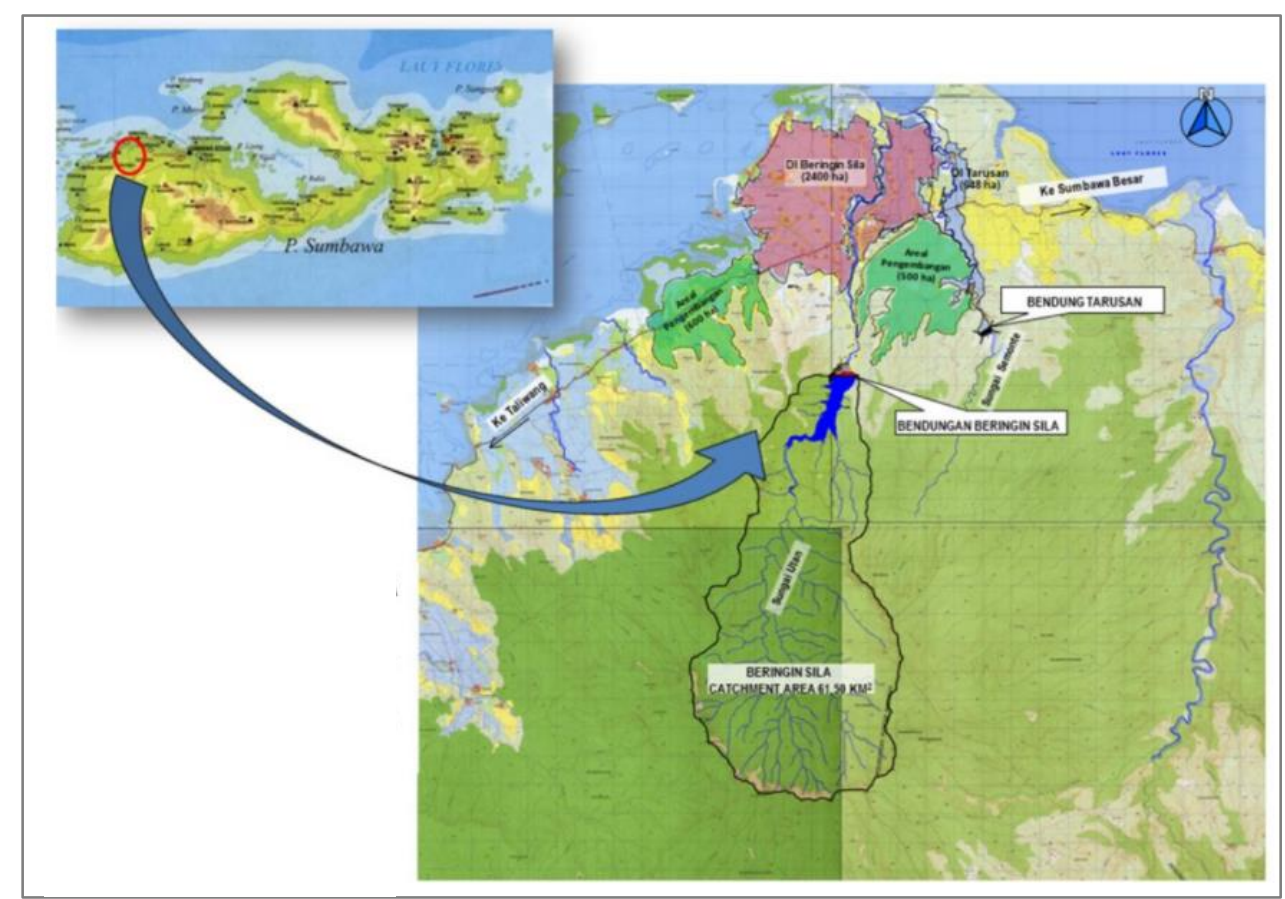

Gambar 1: Lokasi Bendungan Beringin Sila

\subsection{Metode}

Model fisik hidraulik merupakan peniruan bangunan prototipe ke dalam suatu model miniatur skala tertentu, dengan memperhatikan prinsip kesebangunan dan hubungan antar skala parameter yang harus dipenuhi [4]. Fokus dari pengujian model fisik hidrolika bangunan pelimpah samping Bendungan Beringin Sila ini adalah perilaku hidrolika aliran di pelimpah, saluran samping, saluran transisi, saluran peluncur, dan peredam energi.

Alur penelitian dimulai dengan mengumpulkan data teknis bendungan Bendungan Beringin Sila. Setelah memperoleh data teknis dilakukan pembangunan model dengan skala yang di tentukan 1:60 dengan memperhatikan kapasitas Lab Hidrolika yang mencukupi. Lalu di lanjutkan dengan pengujian model fisik, dari uji model test seri 0 atau original design mendapatkan data tinggi muka air dan kecepatan. Kemudian di lanjutkan analisa teoritis perilaku hidrolika aliran dengan menggunakan kajian pustaka untuk memperoleh pendekatan secara hidrolika.

\subsection{Persamaan}

Rumus yang digunakan untuk menghitung debit di atas pelimpah adalah sebagai berikut [5]:

$$
\mathrm{Q}=\text { C.L.H } \mathrm{H}^{3 / 2}
$$

Pers. 1

dengan:

$\mathrm{Q}=$ debit yang melewati pelimpah $\left(\mathrm{m}^{3} / \mathrm{dt}\right)$

$\mathrm{C}=$ koefisien limpahan

$\mathrm{L}=$ lebar efektif mercu pelimpah (m)

$\mathrm{H}=$ total tinggi tekanan air di atas mercu pelimpah (termasuk tinggi tekanan kecepatan aliran pada saluran pengarah aliran) (m). 
Besarnya koefisien debit limpahan $(C)$ dari tipe standar suatu bendung dapat diperoleh dengan rumus Iwasaki [6] sebagai berikut:

$$
\begin{array}{ll}
C_{d}=2,20-0,0416\left(H_{d} / W\right)^{0,990} & \text { Pers. 2 } \\
C=1,60 \frac{1+2 a\left(\frac{h}{H_{d}}\right)}{1+a\left(\frac{h}{H_{d}}\right)} & \text { Pers. 3 }
\end{array}
$$

dengan:

$C=$ koefisien debit limpahan

$C_{d}=$ koefisien debit limpahan pada saat $h=H_{d}$

$h \quad=$ tinggi air di atas mercu pelimpah (m)

$H_{d}=$ tinggi tekan rencana di atas mercu bendung (m)

$W=$ tinggi bendung $(\mathrm{m})$

$a=$ nilai koefisien pada saat $h=H_{d}$ sehingga $C=C_{d}$

Kecepatan aliran teoritis pada pelimpah dapat dihitung dengan rumus sebagai berikut [7] :

$$
\begin{array}{ll}
\mathrm{V}_{\mathrm{z}}=\sqrt{2 \mathrm{~g}\left(\mathrm{Z}+\mathrm{H}_{\mathrm{o}}-\mathrm{y}_{\mathrm{z}}\right)} & \text { Pers. } 4 \\
\frac{\mathrm{Q}}{\mathrm{L}}=\mathrm{V}_{\mathrm{z} \cdot \mathrm{y}_{\mathrm{z}}} & \text { Pers. 5 } \\
\mathrm{Fz}=\frac{\mathrm{V}_{\mathrm{z}}}{\sqrt{\mathrm{g} \cdot \mathrm{y}_{\mathrm{z}}}} & \text { Pers. 6 }
\end{array}
$$

dengan:

$\mathrm{Q}=$ debit aliran $\left(\mathrm{m}^{3} / \mathrm{dt}\right)$

$\mathrm{L}=$ lebar efektif pelimpah

$\mathrm{Vz}=$ kecepatan aliran $(\mathrm{m} / \mathrm{det})$

$\mathrm{g}=$ percepatan gravitasi

$\mathrm{Z}$ = tinggi jatuh atau jarak vertikal dari permukaan hulu sampai lantai kaki hilir (m)

Ho = tinggi tekanan air di hulu (m)

$\mathrm{Yz}=$ kedalaman air di kaki pelimpah $(\mathrm{m})$

$\mathrm{Fz}=$ bilangan Froude

Bentuk mercu pelimpah yang digunakan dalam studi ini adalah berdasarkan metode yang dikembangkan oleh Civil Engineering Department US Army. Rumus yang digunakan untu perhitungan profil pelimpah [6]:

$$
\mathrm{X}^{\mathrm{n}}=\mathrm{K} \cdot \mathrm{Hd}^{\mathrm{n}-1} \cdot \mathrm{Y} \quad \text { Pers. } 7
$$

dengan:

$\mathrm{X} \quad=$ absis

$\mathrm{Y} \quad=$ koordinat permukaan hilir

$\mathrm{K}, \mathrm{n} \quad=$ Parameter (tergantung kemiringan muka pelimpah bagian hulu)

$\mathrm{Hd} \quad=$ tinggi tekan rencana

Debit air yang melintasi mercu pelimpah selalu didasarkan pada lebar efektifnya, yaitu hasil dari pengurangan lebar sesungguhnya dengan jumlah seluruh kontraksi yang timbul pada aliran air yang melintas mercu pelimpah tersebut. Rumus berikut dapat digunakan 
untuk mendapatkan nilai lebar efektif pelimpah dengan mempertimbangkan jumlah pilar dan efek kontraksi pada dinding pelimpah [8]:

$$
\mathrm{L}=\mathrm{L}^{\prime}-2(\mathrm{~N} . \mathrm{Kp}+\mathrm{Ka}) . \mathrm{H} \quad \text { Pers. } 8
$$

dengan:

$\mathrm{L}=$ Lebar efektif pelimpah $(\mathrm{m})$

$\mathrm{L}^{\prime}=$ Lebar bendung sesesungguhnya $(\mathrm{m})$

$\mathrm{N}=$ Jumlah pilar pada mercu pelimpah

$\mathrm{Kp}=$ Koefisien kontraksi pilar

$\mathrm{Ka}=$ Koefisien kontraksi dinding samping

$\mathrm{H}=$ Tinggi tekanan di atas mercu $(\mathrm{m})$

Penentuan tinggi muka air pada mercu pelimpah sebelum adanya perhitungan hidrolika terhadap saluran transisi dan saluran peluncur, hendaknya perlu dilakukan perhitungan hidrolik pada lereng hilir pelimpah guna mengetahui kedalaman air pada hulu saluran transisi. Untuk menentukan kedalaman pada lereng bagian hilir pelimpah tersebut maka digunakan rumus sebagai berikut [7]:

$$
\begin{array}{ll}
V z=\sqrt{ } 2 g(z+H d-Y z) & \text { Pers. } 9 \\
V z=\frac{Q}{Y z \cdot L} & \text { Pers. } 10 \\
F=\frac{V z}{\sqrt{g \cdot y_{z}}} & \text { Pers. 11 }
\end{array}
$$

dengan:

$\mathrm{Vz}=$ Kecepatan aliran di titik sejauh $\mathrm{z}(\mathrm{m})$

$\mathrm{Hd}=$ Tinggi pada hulu pelimpah $(\mathrm{m})$

$\mathrm{Yz}=$ Kedalaman di titik sejauh $\mathrm{z}(\mathrm{m})$

$\mathrm{Q}=$ Debit banjir rencana $\left(\mathrm{m}^{3} / \mathrm{dtk}\right)$

$\mathrm{L}=$ Lebar pelimpah $(\mathrm{m})$

$\mathrm{Fz}=$ Bilangan Froude

$\mathrm{Z}$ = Tinggi mercu dihitung dari puncak mercu hingga hilir lereng pelimpah (m)

Adanya perhitungan tinggi jagaan pada suatu bangunan pelimpah digunakan untuk menghindari terjadinya limpasan, yang kemungkinan terjadi pada elevasi muka air paling tinggi, ditambah tinggi ombak ataupun kemungkinan adanya benda-benda terapung yang terdapat pada aliran tersebut. Disamping untuk menghindari limpasan-limpasan pada elevasi permukaan air disaat dialirkannya debit banjir rencana, tinggi jagaan juga berperan pada saat pengaliran debit banjir abnormal. Untuk perhitungan pada tinggi jagaan dapat digunakan salah satu dari rumus sebagai berikut [6] :

$$
\begin{array}{ll}
\mathrm{Fb}=\mathrm{C} \cdot \mathrm{V} \cdot \mathrm{d}^{1 / 2} & \text { Pers. 12 } \\
\mathrm{Fb}=0,6+0,037 . \mathrm{V} \cdot \mathrm{d}^{1 / 3} & \text { Pers 13 }
\end{array}
$$

$\mathrm{F}_{\mathrm{b}}=$ Tinggi jagaan $(\mathrm{m})$

$\mathrm{C}=$ Koefisien $(0,1$ untuk penampang saluran berbentuk persegi panjang)

$\mathrm{V}=$ Kecepatan aliran $(\mathrm{m} / \mathrm{dtk})$

$\mathrm{d} \quad=$ Kedalaman air didalam saluran $(\mathrm{m})$ 


\section{Hasil dan Pembahasan}

\subsection{Kondisi Hidrolika Pelimpah}

Tahap awal dari pengujian model fisik hidrolik kondisi original design Bangunan Pelimpah Samping Bendungan Beringin Sila Kabupaten Sumbawa adalah tahap kalibrasi. Penetapan skala sangat mempengaruhi akurasi kalibrasi [9], dengan skala yang digunakan pada model fisik ini adalah 1:60. Sehingga dengan skala 1 : 60 hasil model tidak menimbulkan efek skala, dengan pengertian fenomena hidrolika hasil model akan menyerupai prototipe. Parameter yang digunakan adalah tinggi muka air di atas pelimpah (Hd), pada tabel 1 kesalahan relatif terbesar yang diperoleh $1.87 \%$.

Tabel 1: Tingkat Kesalahan Model pada Hd di Atas Pelimpah Bendungan Beringin Sila

\begin{tabular}{ccccc}
\hline \multirow{2}{*}{ Kala Ulang } & $\begin{array}{c}\text { Debit Prototipe } \\
\left(\mathrm{m}^{3} / \mathrm{dt}\right)\end{array}$ & \multicolumn{2}{c}{ Tinggi Muka Air di Atas Pelimpah $(\mathrm{Hd})$} & \multirow{2}{\text{KR}}{} \\
\cline { 3 - 4 } & & $\begin{array}{c}\text { Perhitungan } \\
(\mathrm{m})\end{array}$ & $\begin{array}{c}\text { Model } \\
(\mathrm{m})\end{array}$ & \\
\hline $\mathrm{Q}_{100 \mathrm{th}}$ & 248,36 & 1,60 & 1,57 & 1,87 \\
$\mathrm{Q}_{1000 \mathrm{th}}$ & 390,34 & 2,10 & 2,11 & 0,48 \\
\hline
\end{tabular}

Elevasi muka air pada model pelimpah mampu melewatkan semua debit rancangan yang diujikan tanpa terjadinya aliran balik (backwater). Melihat pada pembacaan piezometer yang terpasang pada pelimpah, tidak menunjukkan adanya nilai negatif pada pengaliran debit banjir rancangan Q100th dan Q1000th sehingga mercu pelimpah aman dari kavitasi. Sehingga secara garis besar perilaku aliran aliran sangat kondusif dengan aliran yang merata di bagian sisi kiri, tengah, dan sisi kanan pelimpah. Pada Tabel 2 perhitungan koefisien debit Cd menggunakan metode Iwasaki diperoleh 2,10 meter per detik.

Tabel 2: Rekapitulasi Nilai Koefisien Limpahan (C) Menurut Iwasaki dan Hasil Uji Model Fisik

\begin{tabular}{ccccccc}
\hline \multirow{2}{*}{ No } & \multirow{2}{*}{ Kala Ulang } & Q outflow & \multicolumn{2}{c}{$\begin{array}{c}\text { Tinggi Muka Air } \\
\text { diatas Pelimpah }(\mathrm{Hd})\end{array}$} & \multicolumn{2}{c}{$\begin{array}{c}\text { Koefisien Limpahan } \\
(\mathrm{Cd})\end{array}$} \\
\cline { 3 - 7 } & & & Model & Iwasaki & Model & Iwasaki \\
\cline { 2 - 7 } & $(\mathrm{mahun})$ & $\left(\mathrm{m}^{3} / \mathrm{dt}\right)$ & $(\mathrm{m})$ & $(\mathrm{m})$ & $\left(\mathrm{m}^{1 / 2} / \mathrm{dt}\right)$ & $\left(\mathrm{m}^{1 / 2} / \mathrm{dt}\right)$ \\
\hline 1 & 100 & 248,36 & 1,58 & 1,54 & 2,10 & 2,18 \\
2 & 1000 & 390,34 & 2,11 & 2,09 & 2,14 & 2,17 \\
\hline
\end{tabular}

\subsection{Kondisi Hidrolika Uji Model Fisik pada Saluran Samping}

Ditinjau dari pemodelan dan pengukuran elevasi muka air, kapasitas saluran samping dengan panjang $60 \mathrm{~m}$ mampu mengalirkan dengan aman pada semua debit rancangan $\left(\mathrm{Q}_{100 t h}\right.$ dan $\left.\mathrm{Q}_{1000 \mathrm{th}}\right)$ yang dioperasikan di model. Sedangkan pada kontrol terhadap bahaya fenoeman kavitasi, pada piezometer yang terpasang pada dasar saluran dasar, tidak menunjukan adanya nilai negatif pada pengaliran debit banjir rancangan ( $\mathrm{Q}_{100 t \mathrm{th}}$ dan $\left.\mathrm{Q}_{1000 \mathrm{th}}\right)$. Sehingga, dapat disimpulkan bahwa saluran samping aman terhadap bahaya 
kavitasi.Kondisi aliran dengan parameternya seperti tinggi muka air, kecepatan aliran dan bilangan Froude pada saluran samping sistem pelimpah sangat dipengaruhi oleh dimensi lebar saluran yang berubah melebar dan slope dasar yang didesain, Pada gambar 1 profil muka air Q100th ditunjukkan dengan garis berwarna hijau dan Q1000th ditunjukkan dengan garis berwarna biru.

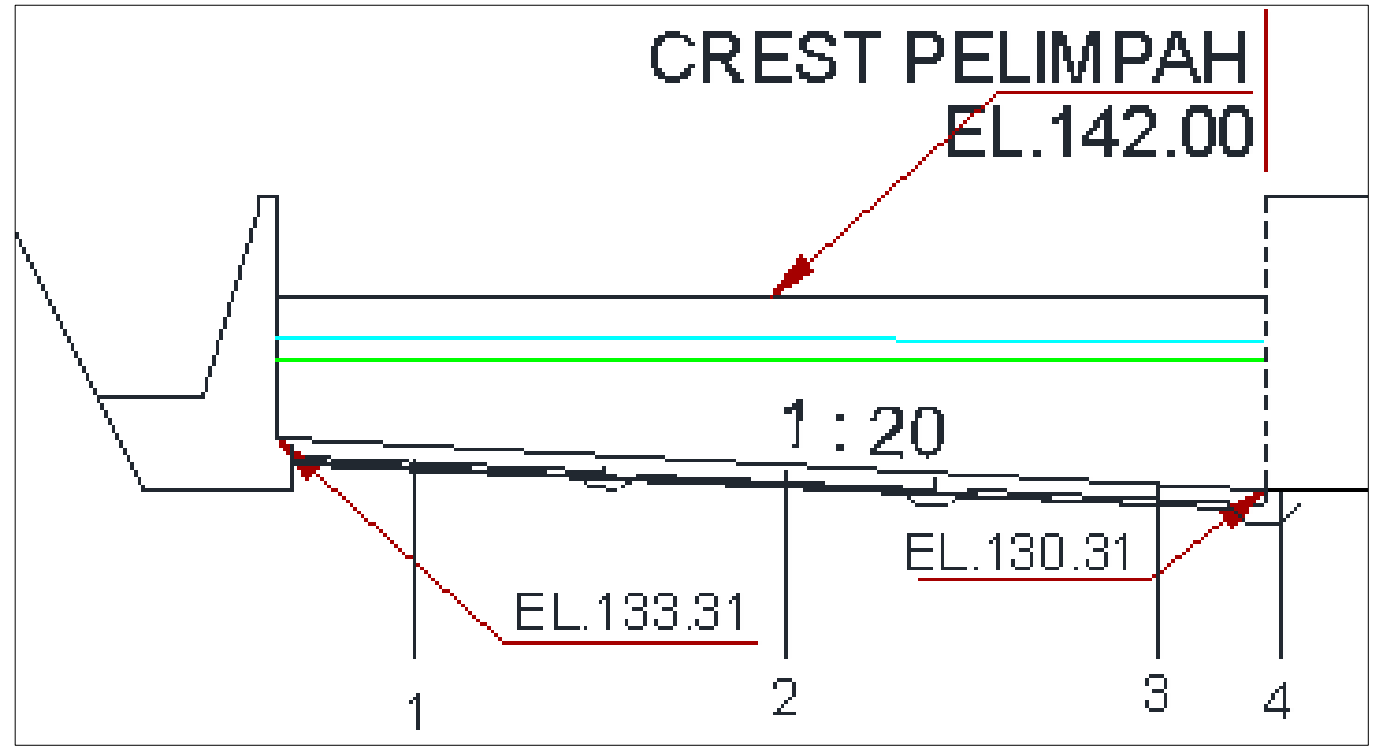

Gambar 2: Profil Muka Air Saluran Samping

Pada Tabel 3 dapat dilihat hasil perbedaan kecepatan dan tinggi muka air pada pengukuran langsung model fisik dan perhitungan anlitis, pada Q100th section 4 perbedaan tinggi muka air sebesar 2,15 meter dan kecepatan 0,22 meter per detik.

Tabel 3: Perbandingan Profil Muka Air Pada Saluran Samping

\begin{tabular}{ccccccccccc}
\hline \multirow{2}{*}{ Kala Ulang } & \multirow{2}{*}{$\begin{array}{c}\text { No. } \\
\text { Section }\end{array}$} & \multicolumn{2}{c}{ Tinggi Muka Air (m) } & \multicolumn{3}{c}{ Kecepatan (m/dt) } & \multicolumn{3}{c}{ Perbedaan (h) } & \multicolumn{3}{c}{ Perbedaan (v) } \\
& 1 & 2,5 & 7,48 & 4,96 & 0,24 & 4,98 & 199,20 & 4,72 & 95,16 \\
& 1 & & Perhitungan & Model & Perhitungan & $\Delta \mathrm{h}$ & $\%$ & $\Delta \mathrm{h}$ & $\%$ \\
\hline \multirow{6}{*}{ (Q100th) } & 2 & 2,5 & 6,33 & 2,27 & 0,77 & 3,83 & 153,20 & 1,50 & 66,08 \\
& 3 & 2,35 & 5,08 & 2,02 & 0,398 & 2,73 & 116,17 & 1,62 & 80,30 \\
& 4 & 2,25 & 4,4 & 2,6 & 2,82 & 2,15 & 95,56 & 0,22 & 8,46 \\
\hline \multirow{4}{*}{ (Q1000th) } & 1 & 4,19 & 8,82 & 2,96 & 0,31 & 4,63 & 110,50 & 2,65 & 89,53 \\
& 2 & 3,81 & 7,66 & 1,47 & 0,97 & 3,85 & 101,05 & 0,50 & 34,01 \\
& 3 & 3,8 & 6,33 & 1,86 & 1,99 & 2,53 & 66,58 & 0,13 & 6,99 \\
& 4 & 3,6 & 5,49 & 2,83 & 3,55 & 1,89 & 52,50 & 0,72 & 25,44 \\
\hline
\end{tabular}

\subsection{Kondisi Hidrolika Uji Model Fisik pada Saluran Transisi}

Perilaku hidrolik aluran pada saluran transisi efektif dalam mengendalikan aliran pada kondisi subkritis sehingga tidak timbul aliran silang untuk setiap debit rancangan (Q100th dan Q1000th) yang dioperasikan di model. Berikut gambar profil muka air saluran transisi 
pelimpah bendungan Beringin Sila. Pada gambar 2 profil muka air Q100th ditunjukkan dengan garis berwarna hijau dan Q1000th ditunjukkan dengan garis berwarna biru dan aliran yang terjadi aman dengan kondisi aliran subkritis.

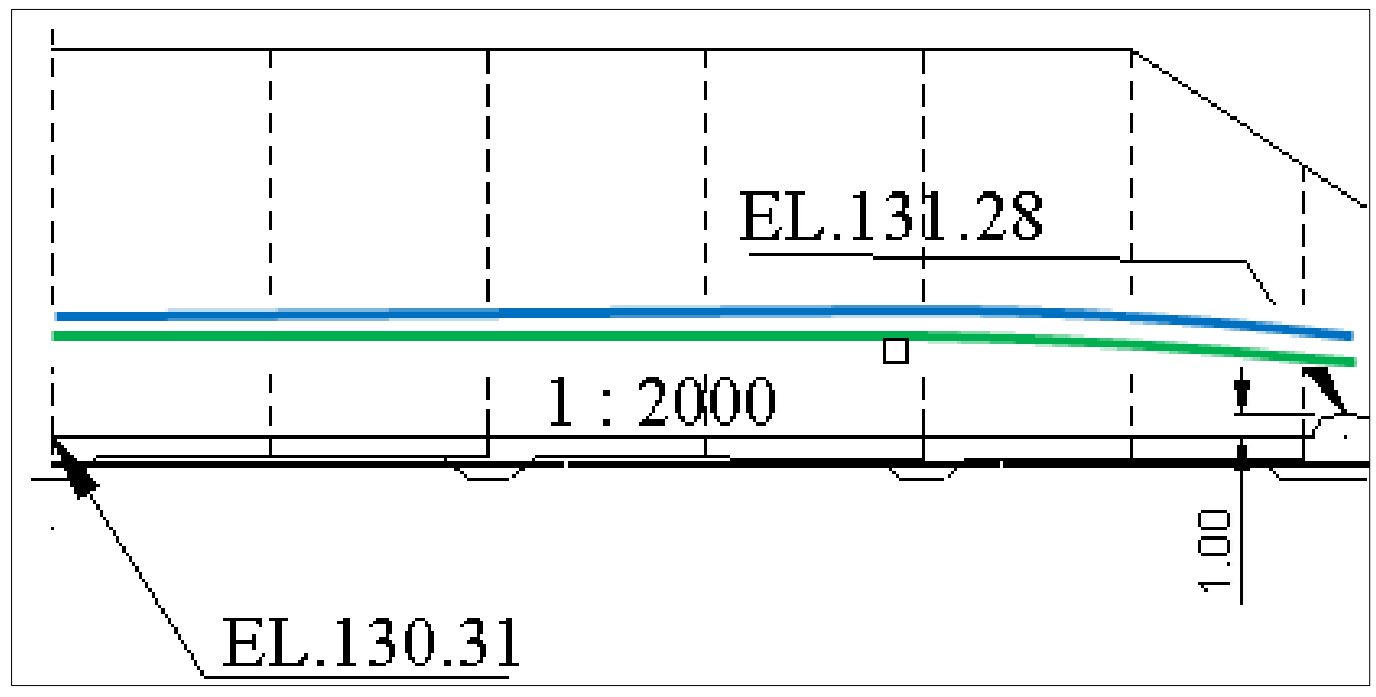

Gambar 3: Profil Muka Air Saluran Transisi

Pada tabel 4 dapat dilihat hasil perbedaan kecepatan dan tinggi muka air pada pengukuran langsung model fisik dan perhitungan anlitis, pada Q100th section 7 perbedaan tinggi muka air sebesar 0,15 meter dan kecepatan 0,39 meter per detik.

Tabel 4: Perbandingan Profil Muka Air pada Saluran Transisi

\begin{tabular}{|c|c|c|c|c|c|c|c|c|c|}
\hline \multirow{2}{*}{ Kala Ulang } & \multirow{2}{*}{$\begin{array}{c}\text { No. } \\
\text { Section }\end{array}$} & \multicolumn{2}{|c|}{ Tinggi Muka Air (m) } & \multicolumn{2}{|c|}{$\operatorname{Kecepatan}(\mathrm{m} / \mathrm{dt})$} & \multicolumn{2}{|c|}{ Perbedaan (h) } & \multicolumn{2}{|c|}{ Perbedaan (v) } \\
\hline & & Model & Perhitungan & Model & Perhitungan & $\Delta \mathrm{h}$ & $\%$ & $\Delta \mathrm{h}$ & $\%$ \\
\hline \multirow{3}{*}{ (Q100th) } & 5 & 2,22 & 4,36 & 2,98 & 2,85 & 2,14 & 96,40 & 0,13 & 4,36 \\
\hline & 6 & 2,16 & 4,33 & 2,94 & 2,87 & 2,17 & 100,46 & 0,07 & 2,38 \\
\hline & 7 & 2,66 & 2,51 & 4,57 & 4,96 & $-0,15$ & 5,64 & 0,39 & 8,53 \\
\hline \multirow{3}{*}{ (Q1000th) } & 5 & 3,01 & 5,44 & 3,58 & 3,58 & 2,43 & 80,73 & 0,00 & 0,00 \\
\hline & 6 & 2,97 & 5,41 & 3,42 & 3,61 & 2,44 & 82,15 & 0,19 & 5,56 \\
\hline & 7 & 3,47 & 3,39 & 5,49 & 5,76 & $-0,08$ & 2,31 & 0,27 & 4,92 \\
\hline
\end{tabular}

3.4 Kondisi hidrolika uji model fisik pada Saluran Peluncur

Bagian peluncur yang memiliki kemiringan cenderung curam, Kondisi aliran dengan parameternya seperti tinggi muka air, kecepatan aliran dan bilangan Froude pada saluran peluncur sistem pelimpah sangat dipengaruhi oleh dimensi lebar saluran, slope dasar yang didesain, dan panjang peluncur.

Pada gambar 3 profil muka air Q100th ditunjukkan dengan garis berwarna hijau dan Q1000th ditunjukkan dengan garis berwarna biru dan kondisi aliran pada saluran peluncur yaitu superkritis dan tidak terdapat kavitasi dan aliran getar. 


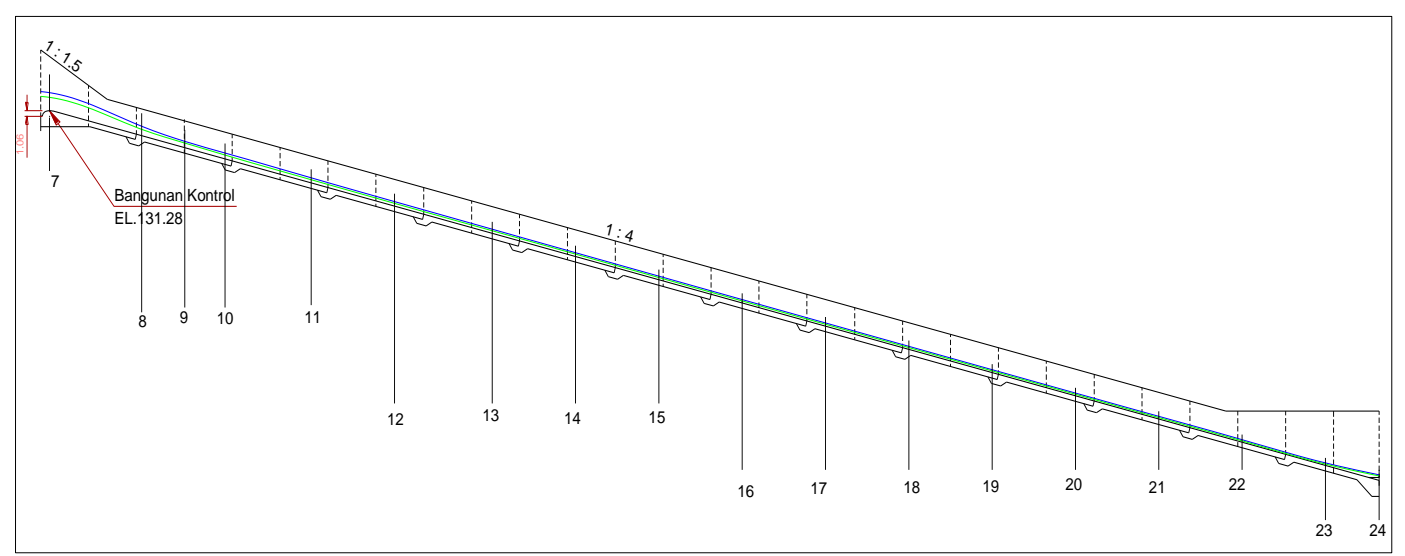

Gambar 3: Profil Muka Air Saluran Peluncur

Pada Tabel 4 dapat dilihat hasil perbedaan kecepatan dan tinggi muka air pada pengukuran langsung model fisik dan perhitungan analitis, pada Q100th section 8 perbedaan tinggi muka air sebesar 0,01 meter dan kecepatan 0,39 meter per detik.

\section{Tabel 4: Perbandingan Profil Muka Air Pada Saluran Peluncur}

\begin{tabular}{|c|c|c|c|c|c|c|c|c|c|}
\hline \multirow{2}{*}{$\begin{array}{l}\text { Kala } \\
\text { Ulang }\end{array}$} & \multirow{2}{*}{$\begin{array}{l}\text { No. } \\
\text { Section }\end{array}$} & \multicolumn{2}{|c|}{ Tinggi Muka Air (m) } & \multicolumn{2}{|c|}{ Kecepatan (m/dt) } & \multicolumn{2}{|c|}{ Perbedaan (h) } & \multicolumn{2}{|c|}{ Perbedaan (v) } \\
\hline & & model & perhitungan & model & perhitungan & $\Delta \mathrm{h}$ & $\%$ & $\Delta \mathrm{v}$ & $\%$ \\
\hline & 8 & 1,2 & 1,19 & 10,07 & 10,46 & 0,01 & 0,83 & 0,39 & 3,87 \\
\hline & 9 & 1,06 & 0,87 & 11,84 & 14,26 & 0,19 & 17,92 & 2,42 & 20,44 \\
\hline & 10 & 1,2 & 0,72 & 13,66 & 17,26 & 0,48 & 40,00 & 3,60 & 26,35 \\
\hline & 11 & 0,82 & 0,61 & 14,94 & 20,52 & 0,21 & 25,61 & 5,58 & 37,35 \\
\hline & 12 & 0,72 & 0,52 & 15,83 & 23,83 & 0,20 & 27,78 & 8,00 & 50,54 \\
\hline & 13 & 0,71 & 0,48 & 17,29 & 26,06 & 0,23 & 32,39 & 8,77 & 50,72 \\
\hline & 14 & 0,68 & 0,45 & 19,17 & 27,89 & 0,23 & 33,82 & 8,72 & 45,49 \\
\hline & 15 & 0,62 & 0,41 & 20,08 & 30,04 & 0,21 & 33,87 & 9,96 & 49,60 \\
\hline \multirow[t]{9}{*}{ (Q100th) } & 16 & 0,56 & 0,39 & 20,73 & 32,21 & 0,17 & 30,36 & 11,48 & 55,38 \\
\hline & 17 & 2,15 & 0,36 & 20,41 & 34,36 & 1,79 & 83,26 & 13,95 & 68,35 \\
\hline & 18 & 0,34 & 0,34 & 20,82 & 36,51 & 0,00 & 0,00 & 15,69 & 75,36 \\
\hline & 19 & 0,72 & 0,32 & 21,07 & 38,92 & 0,40 & 55,56 & 17,85 & 84,72 \\
\hline & 20 & 0,7 & 0,3 & 22,8 & 41,73 & 0,40 & 57,14 & 18,93 & 83,03 \\
\hline & 21 & 0,68 & 0,28 & 22 & 44,24 & 0,40 & 58,82 & 22,24 & 101,09 \\
\hline & 22 & 1,16 & 0,27 & 22,88 & 45,97 & 0,89 & 76,72 & 23,09 & 100,92 \\
\hline & 23 & 1,58 & 0,26 & 21,44 & 47,49 & 1,32 & 83,54 & 26,05 & 121,50 \\
\hline & 24 & 6,48 & 0,29 & & 43,52 & 6,19 & 95,52 & & \\
\hline
\end{tabular}




\subsection{Kondisi Hidrolika Uji Model Fisik pada Peredam Energi}

Kondisi aliran dengan parameternya seperti tinggi muka air, kecepatan aliran dan bilangan Froude pada peredam energi sistem pelimpah sangat dipengaruhi oleh dimensi jenis pemilihan kolam olaknya. Kemudian untuk mengantisipasi gerusan setempat di hilir peredam, maka didesain panjang kolam olak setidaknya setara dengan estimasi panjang loncatan hidroliknya [10].

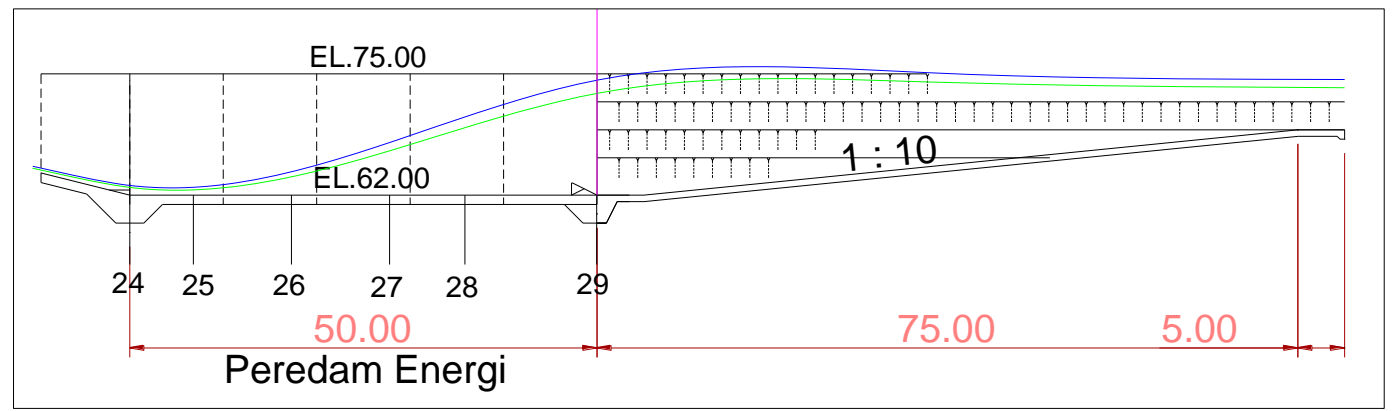

Gambar 4: Profil Muka Air Saluran Peredam Energi

Pada Gambar 4 profil muka air Q100th ditunjukkan dengan garis berwarna hijau dan Q1000th ditunjukkan dengan garis berwarna biru mampu meredam debit ranangan Q100th dan Q1000th.

Tabel 5: Efektifitas Peredaman Energi Bendungan Beringin Sila

\begin{tabular}{cccccccccccc}
\hline \multirow{2}{*}{ Kala ulang } & \begin{tabular}{c} 
Debit \\
\cline { 2 - 2 } $3 / \mathrm{dt}$
\end{tabular} & $\mathrm{m}$ & $\mathrm{m} 2 / \mathrm{dt}$ & $\mathrm{m}$ & $\mathrm{m} 2 / \mathrm{dt}$ & $\mathrm{m}$ & $\mathrm{m}$ & & $\begin{array}{c}\text { Reduksi } \\
\text { Energi }\end{array}$ & $\begin{array}{c}\mathrm{L}_{2} / \mathrm{Y}_{2} \\
\mathrm{~L}_{2}\end{array}$ & $\begin{array}{c}\mathrm{L}_{2} \\
\text { meter }\end{array}$ \\
\hline Q100th & 248.36 & 0.29 & 43.52 & 10.35 & 1.20 & 96.81 & 10.43 & 86.39 & $89 \%$ & 6.10 & 54.36 \\
Q1000th & 390.34 & 0.49 & 39.89 & 12.36 & 1.58 & 81.60 & 12.48 & 69.11 & $85 \%$ & 6.00 & 69.81 \\
\hline
\end{tabular}

Pada Gambar 4 dan Tabel 5 dapat dilihat bahwa peredam energi dengan USBR tipe II masih mampu menampung debit rancangan Q100th dan Q1000th yang lewat dengan efektifitas mereduksi energi sebesar $89 \%$

\section{Kesimpulan}

Berdasarkan analisa perhitungan dan pengujian pada model fisik pelimpah Bendungan Beringin Sila dengan skala 1:60 yang dilakukan sesuai dengan rumusan masalah pada kajian ini, maka dapat disimpulkan beberapa hal sebagai berikut:

a. Pada pelimpah pendekatan hitungan digunakan dengan menghitung koefisien $\mathrm{Cd}$ dengan menggunakan metode Iwasaki diperoleh koefisien limpahan $2,18 \mathrm{~m}^{1 / 2}$

b. Pada saluran samping debit yang masuk Q100th dan Q1000th mampu mengalirkan dengan aman dikarenakan tidak terjadinya aliran balik (back water). Untuk perbandingan profil muka air Q100th pada setion 4 perbedaan kecepatan sebesar $8,46 \%$

c. Pada saluran transisi mampu mengalirkan dengan aman semua debit Q100th dan Q1000th dan aman terhadap aliran silang dan kondisi aliran nya yang sub kritis. Untuk 
perbandingan profil muka air Q1000th pada setion 7 perbedaan kecepatan sebesar $4,92 \%$.

d. Pada saluran peluncur kondisi aliran yaitu superkritis dan aman untuk mengalirakan semua debit rancangan Q100th dan Q1000th dan tidak terjadi kavitasi dan aliran getar. Untuk perbandingan profil muka air Q100th pada section 8 mengalami perdaan kecepatan sebesar 3,87\%.

e. Pada peredam energi USBR tipe 2 secara keseluruhan masih dapat mengalirakan semua debit rancangan Q100th dan Q1000th yang lewat dengan dengan efektifitas mereduksi energi rata - rata sebesar $87 \%$.

\section{Daftar Pustaka}

[1] Anonim, "Profil Pembangunan Bendungan Beringin Sila," Balai Wilayah Sungai Nusa Tenggara I Direktorat Jenderal Sumber Daya Air Kementerian PUPR, 2019. [Online]. Tersedia: https://sda.pu.go.id/balai/bwsnt1/post/108/booklet-profilpembangunan-bendungan-beringin-sila

[2] A. Masrevaniah et. al, "Uji Model Fisik Alternatif Pelimpah Waduk Suplesi Pejok dengan Skala 1:40 (Undistorted Scale)," di Jurnal Teknik Pengairan Vol 1, No 2, 2010 .

[3] R.D. Lufira, et.al," Uji Model Fisik Bangunan Pelimpah Bendungan Saka Gilas Dengan Skala 1:50," di Jurnal Teknik Pengairan, Vol. 10, No. 1, hlm 63-73, Mei 2019.

[4] M. De Vries, Scalling Model Hydraulic. Netherland: IHE Published, 1987.

[5] Anonim, Design of Small Dams. Amerika : United States Department of The Interior, 1987.

[6] S. Sosrodarsono dan K. Nakazawa, Bendungan Tipe Urugan, Jakarta: PT. Pradnya Paramita, 2016.

[7] V.T. Chow, Hidrolika Saluran Terbuka, terjemahan E.V. Nensi Rosalina. Jakarta : Erlangga, 1989.

[8] Anonim, "Chapter 3: General Spillway Design Considerations," dalam Design Standards No. 14: Appurtenant Structures for Dams (Spillways and Outlet Works). Amerika : United States Department of The Interior, 2014.

[9] J.J. Sharp, Hydraulic Modelling. London : Butterworth \& Co. (publishers) Ltd, 1981.

[10] A.J. Peterka, Hydraulic Design of Stilling Basins and Energy Dissipators, 1984. 